\title{
Exploration of multitrait antagonistic microbes against Fusarium oxysporum f.sp. lycopersici
}

\section{Prachi Singh}

Department of Mycology and Plant Pathology, Institute of Agricultural Sciences, Banaras Hindu University, Varanasi- 221005 (Uttar Pradesh), India

Jyoti Singh

Department of Botany, Institute of Science, Banaras Hindu University, Varanasi- 221005 (Uttar Pradesh), India

\section{Rahul Singh Rajput}

Department of Mycology and Plant Pathology, Institute of Agricultural Sciences, Banaras Hindu University, Varanasi- 221005 (Uttar Pradesh), India

\section{Anukool Vaishnav}

Department of Mycology and Plant Pathology, Institute of Agricultural Sciences, Banaras Hindu University, Varanasi- 221005 (Uttar Pradesh), India

\section{Shatrupa Ray}

Department of Mycology and Plant Pathology, Institute of Agricultural Sciences, Banaras Hindu University, Varanasi- 221005 (Uttar Pradesh), India

\section{R.K. Singh}

Department of Mycology and Plant Pathology, Institute of Agricultural Sciences, Banaras Hindu University, Varanasi- 221005 (Uttar Pradesh), India

\section{H.B Singh*}

Department of Mycology and Plant Pathology, Institute of Agricultural Sciences, Banaras Hindu University, Varanasi- 221005 (Uttar Pradesh), India

${ }^{*}$ Corresponding author. E-mail: hbs1@rediffmail.com

\begin{abstract}
Fusarium wilt is one of the major diseases of tomato causing extensive loss of production. Exploration of agriculturally important microbes (AIMs) for management of the tomato wilt is an ecofriendly and cost effective approach. In the present study, a total 30 Trichoderma and 30 bacterial isolates were screened in the laboratory for their biocontrol activity against Fusarium oxysporum f.sp. Iycopersici (FOL). Out of all the isolates tested, Trichoderma asperellum BHU P-1 and Ochrobactrum sp. BHU PB-1 were found to show maximum inhibition of FOL in dual culture assay. Both the microbes also exhibited plant growth promoting activities such as phosphate solubilisation, production of siderophore, hydrogen cyanide (HCN), indole acetic acid (IAA) and protease activity. These microbes could be evaluated further in greenhouse and field studies for their potential use in management of Fusarium wilt of tomato.
\end{abstract}

Keywords: Fusarium oxysporum f.sp. Iycopersici, Trichoderma, Ochrobactrum, Tomato

\section{Article Info}

DOI:10.31018/jans.v11i2.2111

Received: April 30, 2019

Revised: June 3, 2019

Accepted: June 7, 2019

\section{How to Cite}

Singh, P. et al. (2019)

Exploration of multitrait antagonistic microbes against Fusarium oxysporum f. sp. lycopersici. Joumal of Applied and Natural Science, 11(2): $503-510$

https://doi.org/10.31018/

jans.v11i2.2111

\section{INTRODUCTION}

Vegetables are essential source of macro and micronutrients, antioxidants, minerals and dietary fibres in human diet (Wargovich, 2000; Schreinemachers et al. 2018). Among vegetables, tomato with its high nutritional values (source of Vitamin C, Biotin, Vitamin A, Vitamin K, potassium, phosphorus and dietary fibres) plays a crucial role in our daily diet. Although tomato production is hampered by several diseases such as Fusarium wilt, early blight, damping off, tomato spotted wilt, bacterial wilt etc. Fusarium oxysporum f.sp. lycopersi- ci (FOL), but wilt pathogen causes profound loss to tomato production worldwide. FOL, a soil-borne pathogen, persists in soil for about 8-10 years in the form of chlamydospores as resting structure (Katan 1971). Management of Fusarium oxysporum is done by chemical pesticides such as pentachloronitrobenzene (PCNB) and soil fumigants as vapam, chloropicrin and methyl bromide. These agrochemicals are associated with several issues including phytotoxicity, pesticide residue, health hazards and increased cost (Stevens et al. 2003). Escalated use of chemical fertilizers and pesticides has aggravated the soil and water con- 
ditions due to chemical residue accumulation. The chemical residue enters the food chain imposing serious hazards to human health and thus there is need to look for safer alternative to chemical fertilizers and pesticides. In this context, the use of agriculturally important microbes (AIMs) have emerged as an environmental friendly approach to boost up agricultural production by strengthening plant defense and promoting plant growth.

AIMs comprising of soil/rhizospheric fungi and bacteria such as Trichoderma, Pseudomonas, Bacillus, Azospirillum etc. have antagonistic activity against soil-borne fungal pathogens and potentiality to enhance plant growth (Choudhary et al. 2016). AlMs involve various mechanisms for antagonism such as hyperparasitism, production of antibiotics, hydrolytic enzymes, toxins, competition for nutrients and induce systemic resistance in plants (Vinale et al. 2008; Vaishnav et al. 2014; Singh 2014a; Bisen et al. 2016). AIMs possess several plant growth promoting properties like: phosphate solubilisation, production of siderophore, phytohormones and ACC-deaminase activity. These growth promoting properties, augment plant growth and development through increase nutrient/ water uptake efficiency, root/ shoot length, number of root/shoot, phytohormone signalling and antioxidant activities (Perrig et al. 2007; Vaishnav et al. 2016; Kumar et al. 2017).

In the present study, antagonistic microbes including fungal spp. and bacterial spp. were isolated from agriculture field soil samples collected from different location of Varanasi district, Uttar Pradesh, India and evaluated against the Fusarium wilt pathogen of tomato. These were also evaluated for their plant growth promotion activities such as phosphate solubilisation, siderophore production, IAA production, HCN production and protease activity with an objective of their exploitation as biofertilizer and biopesticides after field testing and assessment.

\section{MATERIALS AND METHODS}

Collection of soil samples: Soil samples were collected from agricultural field of five different location of Varanasi district - BHU agricultural farm, Jakhini, Adalpura, Laskariya and Ramnagar from which about 25 different fungal isolates and 25 different bacterial isolates were recovered. In addition, five Trichoderma and five bacterial strains each were taken from Biological control laboratory, Department of Mycology and Plant Pathology, Banaras Hindu University, Varanasi, India.

Isolation and purification of agriculturally important microbes: Isolation of AIMs from soil was done by serial dilution upto $10^{-7}$ dilution in sterile distilled water followed by plating on Trichoderma selective medium for isolation of Trichoderma and plating on Nutrient agar medium for isolation of bacterial isolates. Single colonies of fungi and bacteria were transferred on fresh culture media. In vitro screening of agriculturally important microbes

On the basis of antagonistic potential: Isolated microbes were screened for their antagonistic potential against Fusarium oxysporum f.sp. lycopersici by dual culture assay. A $2 \mathrm{~mm}$ of Fusarium mycelia plug grown on agar plate was placed at a distance of $2 \mathrm{~cm}$ from the edge of the PDA agar plate and challenged on the other end of the plate at $2 \mathrm{~cm}$ from edge with a $2 \mathrm{~mm}$ plug of Trichoder$m a$ as shown in Fig. 2. Streaking was done in case of bacterial isolates. Petriplates were kept for incubation at $28 \pm 2^{\circ} \mathrm{C}$ and after 7 days of incubation, percent $(\%)$ inhibition of the FOL against each isolate was calculated using the following formula:

$\mathrm{I}=(\mathrm{C}-\mathrm{T}) \times 100 / \mathrm{C}$

Where, $\mathrm{I}=\%$ inhibition in mycelia growth; $\mathrm{C}=$ growth of pathogen in control plates; $T=$ growth of pathogen in dual culture plates.

On the basis of plant growth promoting (PGP) traits: All the isolates were assessed for plant growth promotion attributes including phosphate solubilisation and production of siderophore, $\mathrm{HCN}$, IAA and protease activity.

Phosphate solubilisation assay: Screening for phosphate solubilisation was done on NBRI-BPB agar plate supplemented with $0.8 \mathrm{mM}$ calcium triphosphate and $0.5 \mathrm{mM}$ glucose and activity was evaluated according to method devised by Mehta and Nautiyal (2001) and King (1932).

Siderophore production assay: The isolates were screened for siderophore production according to Schwyn and Neilands (1987) by inoculation on chromo azurol Sulphonate medium agar plates followed by incubation at $28 \pm 2^{\circ} \mathrm{C}$ for $72 \mathrm{hr}$. Discolouration of medium around culture indicated positive result.

Indole acetic acid (IAA) assay: The isolates were screened for indole acetic acid production according to Loper and Scroth (1986). The fungal isolates were inoculated in PDB and bacterial in NB medium amended with tryptophan $(5 \mathrm{mM})$ in glass vials and incubated at $28 \pm 2^{\circ} \mathrm{C}$ for $72 \mathrm{hr}$ at $120 \mathrm{rpm}$. After incubation, culture was centrifuged at $10,000 \mathrm{rpm}$ for $10 \mathrm{~min}$. at $4^{0} \mathrm{C}, 2 \mathrm{ml}$ of supernatant was taken in separate test tube and $4 \mathrm{ml}$ of Salkowski's reagent $(50 \mathrm{ml}$ of $35 \%$ perchloric acid and $1 \mathrm{ml}$ of $0.5 \mathrm{M}$ ferric chloride) was added (Gordon and Weber 1951). Above mixture was incubated at room temperature for $30 \mathrm{~min}$ and development of pink red colour was recorded as positive.

HCN production assay: The isolates were screened for HCN production according to Bakker and Schipper (1987). The fungal isolates were inoculated in PDB and bacterial in NB medium in glass vials amended with $4.4 \mathrm{~g}$ glycine/l. Flags of 
whatman filter paper, dipped in $2 \%$ sodium carbonate prepared in $0.5 \%$ picric acid was placed at edge of the vials and were incubated at $28 \pm 2^{\circ} \mathrm{C}$ for $72 \mathrm{hr}$. The change in colour of flags from yellow to dark brown indicated positive results.

Protease production assay: Protease production assay was performed according to Liu et al. (2009) with slight modification. Isolates inoculated on skimmed milk agar plates were incubated at $28 \pm 2^{\circ} \mathrm{C}$ for $72 \mathrm{hr}$. Positive test was indicated by appearance of clear zone around colonies.

Identification of potential isolates: One fungal and one bacterial isolates possessing all PGP traits and antagonistic potential were selected for molecular identification by ITS and 16S rRNA gene sequencing. For molecular identification, DNA isolation of both the isolates was done by CTAB method, followed by PCR amplification of rRNA genes with their respective ITS and 165 primer.

Statistical analysis: Experiments were repeated using completely randomized design. The data are expressed as the mean of three independent replications \pm standard deviations. Means were compared by Duncan's multiple range tests ( $p \leq$ 0.05) using SPSS version 20.

\section{RESULTS}

Isolation of AIMs isolates from different location of Varanasi district: A total of 25 isolates were recovered each of fungi and bacteria from five different locations of Varanasi district. In detail, 5 isolates of each fungi and bacteria from Jakhini, 4 isolates of fungi and 6 isolates of bacteria from Adalpura, 7 isolates of fungi and 6 isolates of bacteria from $\mathrm{BHU}$ agricultural farm, 4 isolates of fungi and 4 isolates of bacteria from Laskariya and 5 isolates of fungi and 4 isolates of bacteria from Ramnagar.
Screening of isolates against Fusarium oxysporum f.sp. lycopersici: Out of total, 30 fungi and 30 bacterial isolates, 10 of fungi and 5 bacterial isolates showed significant reduction in colony diameter of FOL over control. Fungal isolate $\mathrm{BHU}$ $\mathrm{P} 1$ showed maximum percent inhibition $\left(82.49 \pm 0.46^{\mathrm{a}}\right)$ and minimum percent inhibition was exhibited by BHU P24 $\left(72.84 \pm 0.39^{\mathrm{e}}\right)$ (Fig 1, 2). Whereas among bacterial isolate BHU PB1 showed maximum reduction in colony diameter $\left(52.21 \pm 0.54^{f}\right)$ and minimum reduction was recorded by BHU B4 $\left(18.86 \pm 0^{j}\right)$ (Fig 1, 2).

Assessment of the plant growth promotion ability of isolates: Out of all isolates, three fungal isolate BHU P1, BHU P4, BHU P13 and three bacterial isolate $\mathrm{BHU} \mathrm{PB} 1, \mathrm{BHU} \mathrm{B} 3, \mathrm{BHU}$ B5 with antagonistic potential against FOL also showed plant growth promotion activity. Fungal isolates BHU P1 and bacterial isolate BHU PB1 exhibited high level of all the tested PGP activities (phosphate solubilisation, siderophore production, IAA production, HCN production, protease activity) (Table 1 and Fig 3).

Identification of the most potential fungal and bacterial isolate: The fungal isolate $\mathrm{BHU} P 1$ and bacterial isolate BHU PB1 with highest antagonistic potential against FOL and all the PGP activities (phosphate solubilisation, siderophore production, IAA production, HCN production, protease activity) were identified as Trichoderma asperellum BHU P -1 (MK 256334) (Fig 4) and Ochrobactrum sp. BHU PB-1(MK587668) (Fig 5) respectively. Sequences were submitted in GenBank database, NCBI.

\section{DISCUSSION}

In this study, we have isolated about 25 fungal and 25 bacterial isolates from agricultural field soil of Varanasi district. In addition, 5 each fungal and

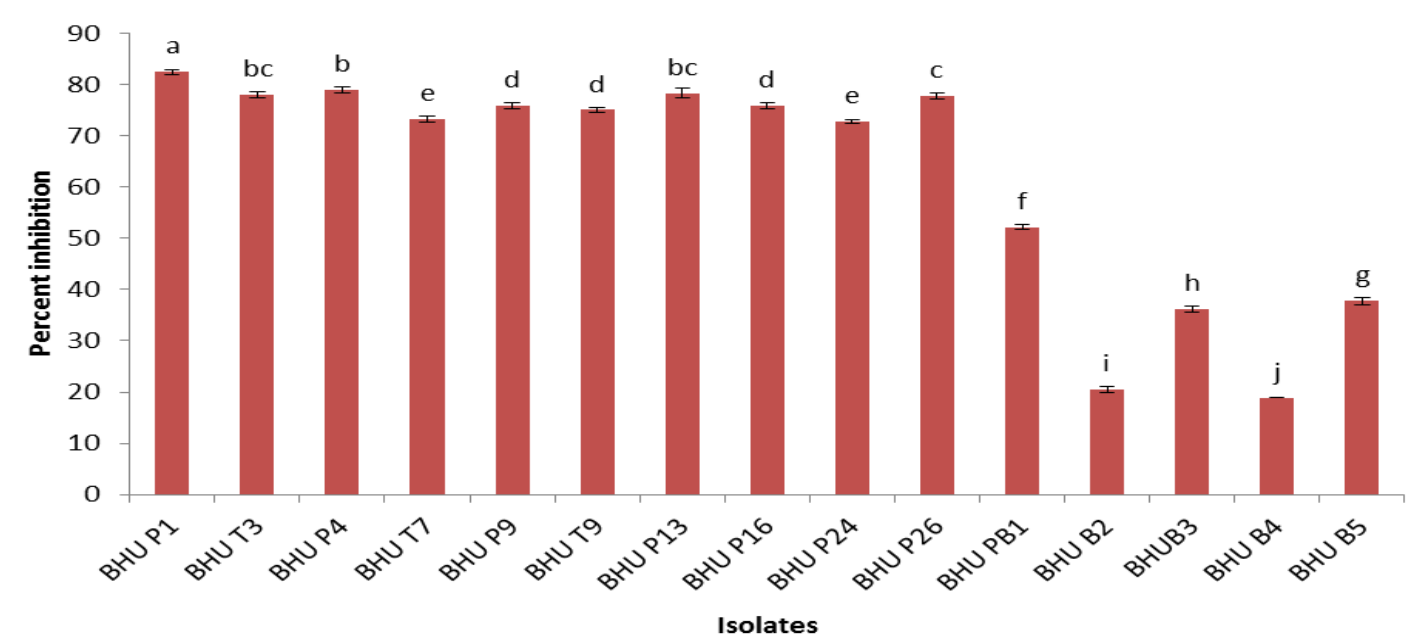

Fig. 1. Percent inhibition of FOL by fungal and bacterial isolates. Results are expressed as means of three replication and vertical bar indicate the standard deviation of the means. Different letters indicate significant differences among treatments according to Duncan's multiple range tests at $p \leq 0.05$. 
Singh, P. et al. / J. Appl. \& Nat. Sci. 11(2): 503 - 510 (2019)
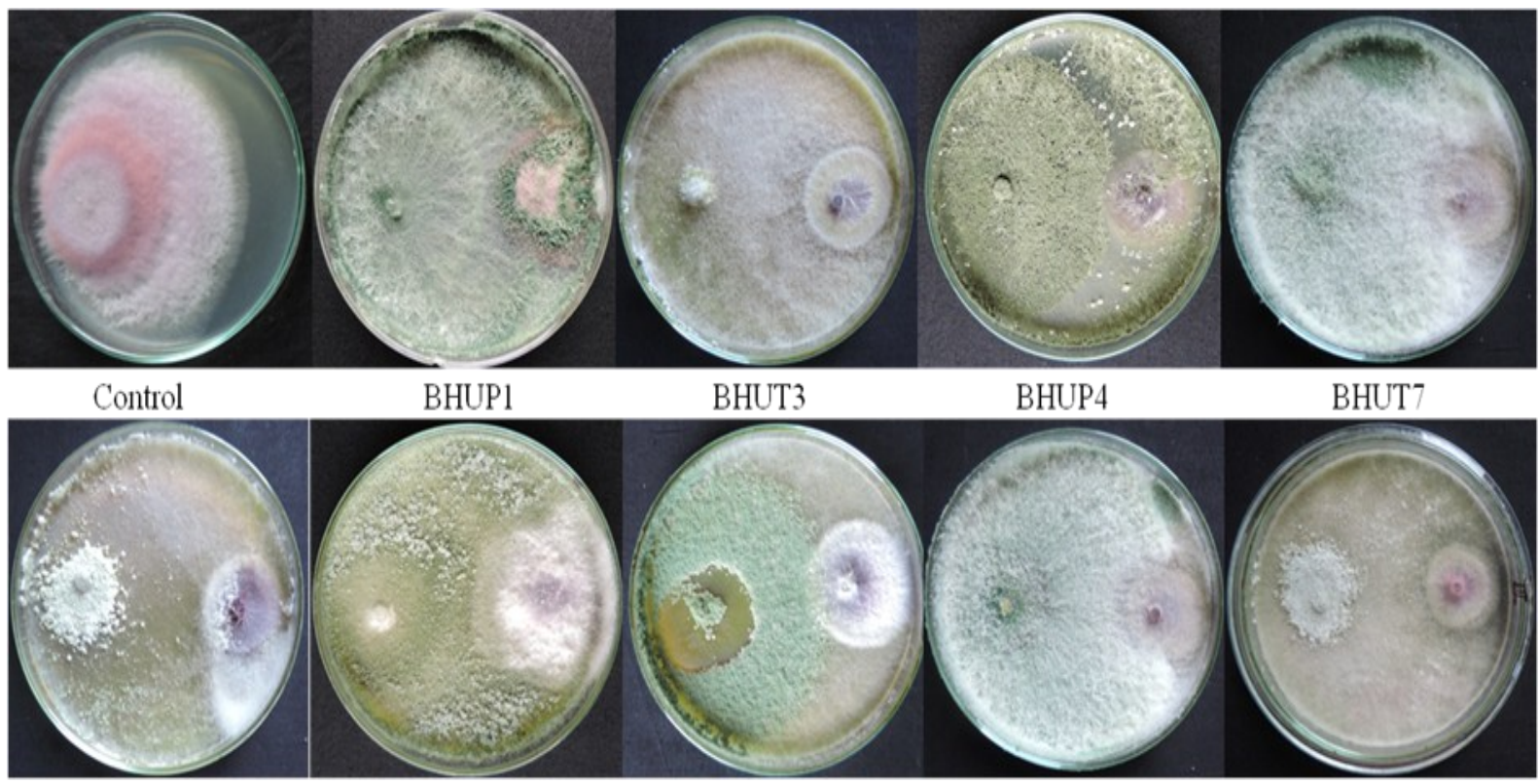

BHUP9

BHUT9

BHUP13

BHUP16

BHUP24

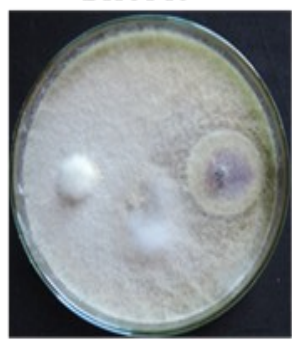

BHUP26

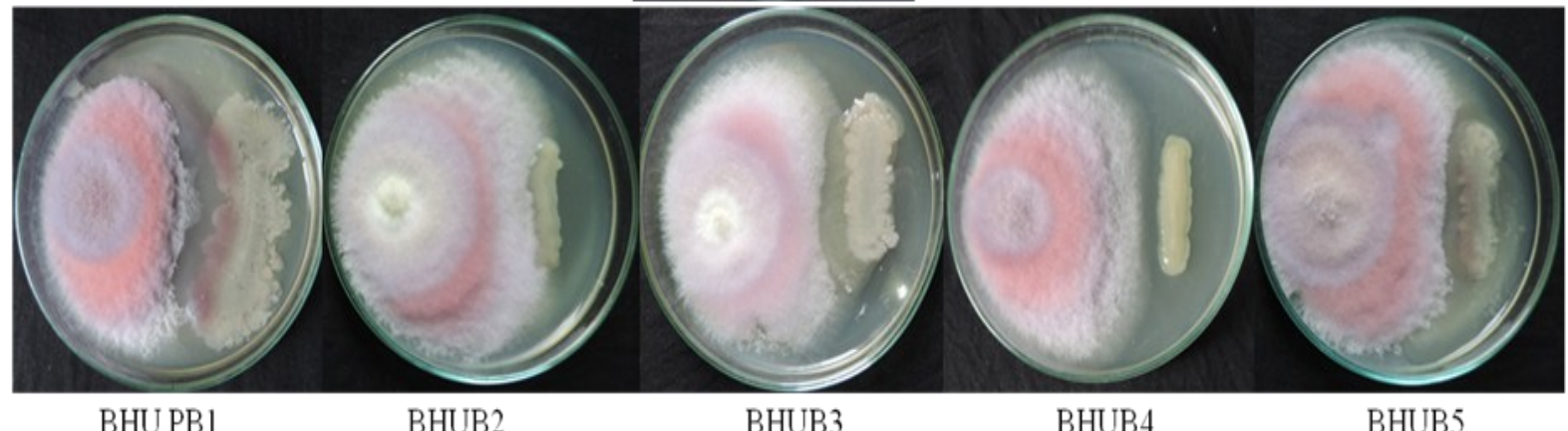

BHU PBI

BHUB2

BHUB3

BHUB4

BHUB5

Fig. 2. Dual culture assay of Fungal and bacterial isolates against FOL.

Table 1. List of fungal and bacterial isolates showing PGP activities tested.

\begin{tabular}{|c|c|c|c|c|c|}
\hline Isolates & $\begin{array}{l}\text { Phosphate } \\
\text { solubilization }\end{array}$ & $\begin{array}{l}\text { Siderophore } \\
\text { production }\end{array}$ & IAA production & HCN production & $\begin{array}{l}\text { Protease } \\
\text { activity }\end{array}$ \\
\hline \multicolumn{6}{|l|}{ Fungi } \\
\hline BHU P1 & +++ & +++ & +++ & +++ & ++ \\
\hline BHU P4 & ++ & ++ & ++ & ++ & + \\
\hline BHU P13 & + & ++ & ++ & ++ & ++ \\
\hline \multicolumn{6}{|l|}{ Bacteria } \\
\hline BHU PB1 & +++ & +++ & +++ & ++ & +++ \\
\hline BHU B3 & + & ++ & ++ & - & +++ \\
\hline BHU B5 & - & + & ++ & - & + \\
\hline
\end{tabular}

+++ = High; ++ = Moderate; + =Low and; - =absence 
Singh, P. et al. / J. Appl. \& Nat. Sci. 11(2): 503 - 510 (2019)
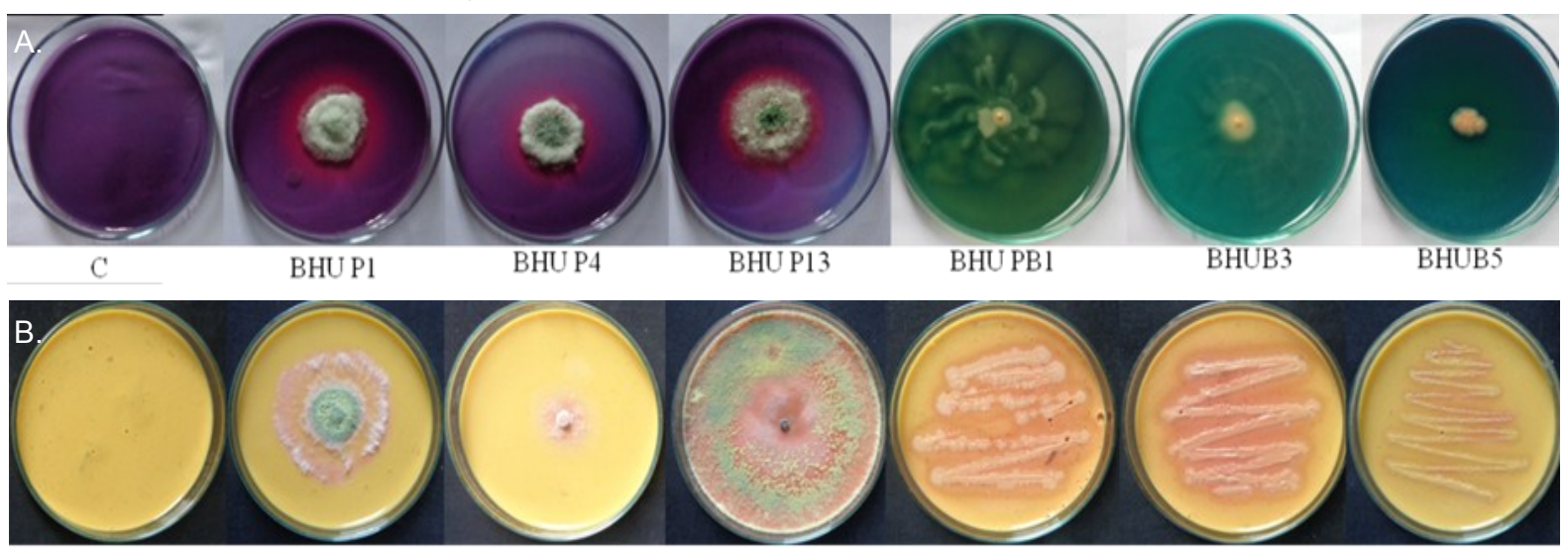

C

BHUPl

BHU P4

BHU P13

BHU PBI

BHUB3

BHUB5
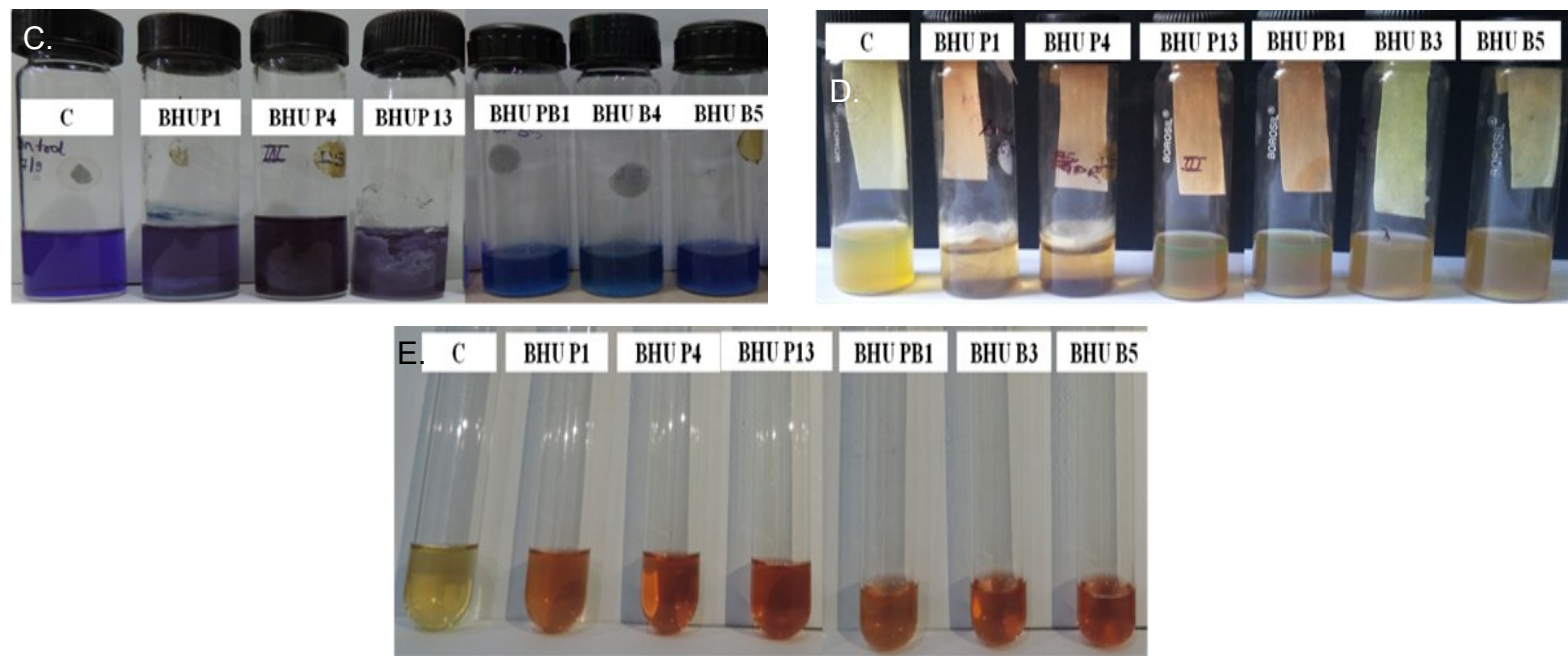

Fig 3. Plant growth promotion activity assays. A- siderophore production assay, B-protease activity assay, C-Phosphate solubilisation, D- HCN production, E- IAA production assay of fungal and bacterial isolates.

bacterial isolates were collected from Department of Mycology and Plant Pathology, Institute of Agricultural Sciences, BHU, Varanasi, India. These isolates were further screened for antagonistic activity against FOL and their plant growth promotion attributes as indicated by phosphate solubilisation, IAA production, siderophore production, $\mathrm{HCN}$ production and protease activity in order to select, most promising isolates for further study. Out of all tested isolates, Trichoderma asperellum BHU-P1 and Ochrobactrum sp. BHU-PB1 exhibited highest antagonistic potential against FOL and possessed all PGP activities tested. Protease and $\mathrm{HCN}$ activities have been reported to control growth of phytopathogens (Elad 2000, Rijavec and Lapanje 2016). Phosphate solubilisation activity solubilises inorganic phosphate in soil and enhances phosphate uptake by plant (Richardson et al., 2009). Siderophores are iron chelating agents, which increases iron uptake efficiency in plants whereas IAA is a plant hormone responsible for root development (Datta and Basu, 2000;
Sharma and Johri 2003). Microbial mediate IAA production in rhizosphere could enhance root length and lateral root formation leading to more uptakes of water and nutrients in plants (Vacheron et al. 2013). Trichoderma spp. and bacterial genera as Pseudomonas, Bacillus, Ochrobactrum, Azospirillum, Achromobacter and Flavobacterium have previously been isolated from soil which showed beneficial effects on plant growth and development (Felici et al. 2008; Adesina et al. 2007; Forchetti et al. 2007; Swain and Ray 2009; Kumari et al. 2015). In addition, several reports further established that the plant growth promotion and diseases suppression ability of AIMs was due to multiple PGP factors (Grondona et al. 1997; Howell 2003; Antoun and Prévost 2005; Bashan and de-Bashan 2010; Jain et al. 2014). Single AIMs have been often reported to exhibit multiple mechanism of action including biological control (Howell 2003; Antoun and Prévost 2005; Singh et al. 2014b). Our results in the laboratory suggested that Trichoderma asperellum BHU-P1 and Ochro- 


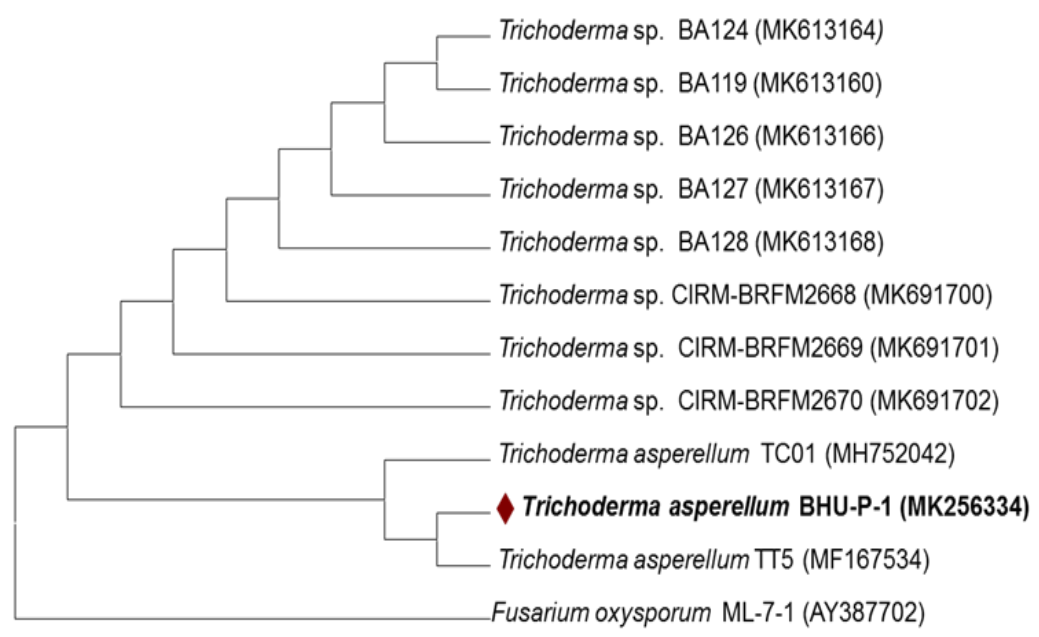

Fig. 4. Phylogenetic tree of Trichoderma asperellum strain BHU P-1 based on ITS gene sequence. Bootstrap values are based on 1000 replications. The isolate whose sequences have been submitted in NCBI GenBank are highlighted with brown colour symbol with their respective Accession number.

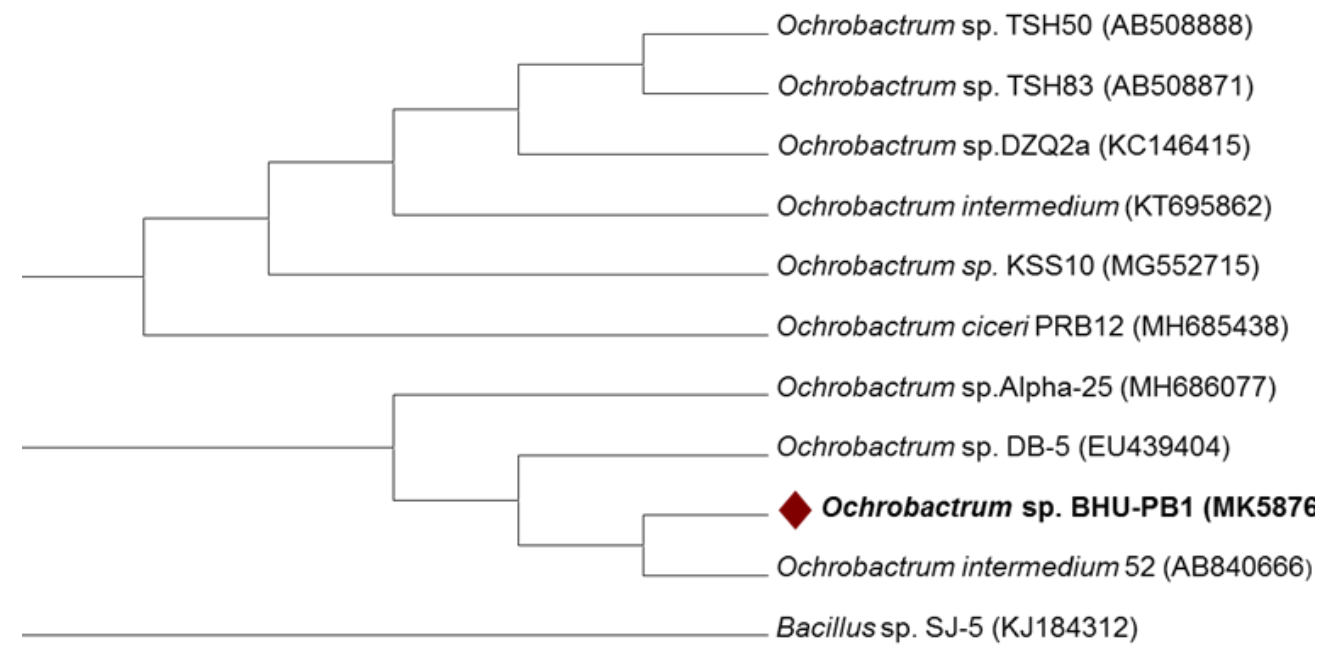

Fig. 5. Phylogenetic tree of Ochrobactrum sp. strain BHU- PB1 based on 16SrRNA gene sequence. Bootstrap values are based on 1000 replications. The isolate whose sequences have been submitted in NCBI GenBank are highlighted with brown colour symbol with their respective Accession number.

bactrum sp. BHU-PB1 have potential for management of Fusarium wilt of tomato and enhancement of growth and productivity. These microbes need to be evaluated further in greenhouse and multiple field trials. If found suitable these can subsequently be considered for developing suitable formulations, and commercialization.

\section{Conclusion}

The above laboratory study reports two most promising AIMs viz. Trichoderma asperellum $\mathrm{BHU}$ $\mathrm{P} 1$ and Ochrobactrum sp. BHU PB-1 based on their antagonistic potential against FOL and PGP activities. These isolates could further be evaluat- ed for greenhouse and field studies, to validate their biological control and plant growth promotion ability on different crop plants.

\section{ACKNOWLEDGEMENTS}

P. Singh and R. S. Rajput are grateful to UGCRET fellowship for providing financial assistance.

\section{REFERENCES}

1. Adesina, M. F., Lembke, A., Costa, R., Speksnijder, A., andSmalla, K. (2007). Screening of bacterial isolates from various European soils for in vitro antagonistic activity towards Rhizoctonia solani and Fusarium oxysporum: Site-dependent composition and 
diversity revealed. Soil Biology and Biochemistry, 39 (11), 2818-2828.

2. Antoun, H., and Prévost, D. (2005). Ecology of plant growth promoting rhizobacteria. . PGPR: biocontrol and biofertilization. Springer, Dordrecht, 1-38.

3. Bakker, A.W., and Schipper, B. (1987). Microbial cyanide production in the rhizosphere in relation to potato yield reduction and Pseudomonas spp. mediated plant growth stimulation. Soil Biology Biochemistry, 19, 451-457

4. Bashan, Y., andDe-Bashan, L. E. (2010). How the plant growth-promoting bacterium Azospirillum promotes plant growth-a critical assessment. Advances in agronomy (Vol. 108), Academic Press, pp. 77136

5. Bisen, K., Keswani, C., Patel, J. S., Sarma, B. K., andSingh, H. B. (2016). Trichoderma spp.: efficient inducers of systemic resistance in plants. Microbialmediated induced systemic resistance in plants. Springer, Singapore, pp 185-195.

6. Choudhary, D. K., Kasotia, A., Jain, S., Vaishnav, A., Kumari, S., Sharma, K. P., and Varma, A. (2016). Bacterial-mediated tolerance and resistance to plants under abiotic and biotic stresses. Journal of Plant Growth Regulation, 35(1), 276-300.

7. Datta, C., and Basu, P. (2000). Indole acetic acid production by a Rhizobium species from root nodules of a leguminous shrub Cajanus cajan. Microbiological Research, 155, 123 - 127.

8. Elad, Y. (2000). Biological control of foliar pathogens by means of Trichoderma harzianum and potential modes of action. Crop Protection, 19(8-10), 709-714.

9. Felici, C., Vettori, L., Giraldi, E., Forino, L. M. C., Toffanin, A., Tagliasacchi, A. M., and Nuti, M. (2008). Single and co-inoculation of Bacillus subtilis and Azospirillum brasilense on Lycopersicon esculentum: effects on plant growth and rhizosphere microbial community. Applied Soil Ecology, 40(2), 260-270.

10.Forchetti, G., Masciarelli, O., Alemano, S., Alvarez, D., and Abdala, G. (2007). Endophytic bacteria in sunflower (Helianthus annuus L.): isolation, characterization, and production of jasmonates and abscisic acid in culture medium. Applied Microbiology and Biotechnology, 76(5), 1145-1152.

11.Gordon, S. A., and Weber, R. P. (1951). Colorimetric estimation of indole acetic acid. Plant Physiology, 26, 192-195. DOI: 10.1104/pp.26.1.192

12.Grondona, I., Hermosa, R., Tejada, M., Gomis, M.D., Mateos, P.F., Bridge, P.D., Monte, E. and GarciaAcha, I. (1997). Physiological and biochemical characterization of Trichoderma harzianum, a biological control agent against soilborne fungal plant pathogens. Applied and Environmental Microbiology, 63 (8), 3189-3198.

13. Howell, C. R. (2003). Mechanisms employed by Trichoderma species in the biological control of plant diseases: the history and evolution of current concepts. Plant Disease, 87(1), 4-10.

14.Jain, S., Vaishnav, A., Kasotia, A., Kumari, S., and Choudhary, D.K. (2014). Plant growthpromoting bacteria elicited induced systemic resistance and tolerance in plants. Emerging Technologies and Management of Crop Stress Tolerance Volume 2, Elsevier, pp 109-132 DOI: 10.1016/B978-0-12-800875-1.00005_3

15.Katan, J. (1971). Symptomless carriers of the tomato Fusarium wilt pathogen. Phytopathology, 61(10),
1213-1217.

16.King, J.E. (1932). The colorimetric determination of phosphorus. Biochemistry Journal, 26: 292.

17.Kumar, G., Maharshi, A., Patel, J., Mukherjee, A., Singh, H. B., and Sarma, B. K. (2017). Trichoderma: a potential fungal antagonist to control plant diseases. SATSA Mukhapatra-Annual Technical Issue, 21, 206-218.

18.Kumari, S., Vaishnav, A., Jain, S., Varma, A., and Choudhary, D. K. (2015). Bacterial-mediated induction of systemic tolerance to salinity with expression of stress alleviating enzymes in soybean (Glycine max L. Merrill). Journal of Plant Growth Regulation, 34(3), 558-573.

19.Liu, C. H., Chiu, C. S., Ho, P. L., and Wang, S. W. (2009). Improvement in the growth performance of white shrimp, Litopenaeus vannamei, by a proteaseproducing probiotic, Bacillus subtilis E20, from natto. Journal of Applied Microbiology, 107(3)1031-1041.

20.Loper, J. E., and Schroth, M. N. (1986). Influence of bacterial sources of indole-3-acetic acid on root elongation of sugar beet. Phytopathology, 76(4), 386-389.

21. Mehta, S., and Nautiyal, C. S. (2001). An efficient method for qualitative screening of phosphatesolubilizing bacteria. Current Microbiology, 43(1):5156

22.Perrig, D., Boiero, M. L., Masciarelli, O. A., Penna, C., Ruiz, O. A., Cassán, F. D., and Luna, M. V. (2007). Plant-growth-promoting compounds produced by two agronomically important strains of Azospirillum brasilense, and implications for inoculant formulation. Applied Microbiology and Biotechnology, 75 (5), 1143-1150.

23.Richardson, A. E., Barea, J. M., McNeill, A. M., and Prigent-Combaret, C. (2009). Acquisition of phosphorus and nitrogen in the rhizosphere and plant growth promotion by microorganisms. Plant and Soil, 321(12), 305-339.

24.Rijavec, T., and Lapanje, A. (2016). Hydrogen cyanide in the rhizosphere: not suppressing plant pathogens, but rather regulating availability of phosphate. Frontiers in Microbiology, 7, 1785.

25.Schreinemachers, P., Simmons, E. B., and Wopereis, M. C. (2018). Tapping the economic and nutritional power of vegetables. Global Food Security, 16, 36-45.

26.Schwyn, B., and Neilands, J.B. (1987). Universal chemical assay for the detection and determination of siderophores. Analytical Biochemistry, 160: 47-56.

27.Sharma, A., and Johri, B. N. (2003). Growth promoting influence of siderophore-producing Pseudomonas strains GRP3A and PRS9 in maize (Zea mays L.) under iron limiting conditions. Microbiological Research, 158(3), 243-248.

28.Singh HB (2014a) Management of plant pathogens with microorganisms. Proceeding of National Academy of Science, 80: 443-454

29.Singh, H. B., Singh, A., Sarma, B. K., and Upadhyay, D. N. (2014b). Trichoderma viride $2 \%$ WP (Strain No. BHU-2953) formulation suppresses tomato wilt caused by Fusarium oxysporum f. sp. lycopersici and chilli damping-off caused by Pythium aphanidermatum effectively under different agroclimatic conditions. International Journal of Agriculture Environment and Biotechnology, 7, 313-320.

30.Stevens, C., Khan, V.A., Rodriguez-Kabana, R., Ploper, L.D., Backman, P.A., Collins, D.J., Brown, 
J.E., Wilson, M.A. and Igwegbe, E.C.K. (2003). Integration of soil solarization with chemical, biological and cultural control for the management of soilborne diseases of vegetables. Plant and Soil, 253(2):493506

31.Swain, M. R., and Ray, R. C. (2009). Biocontrol and other beneficial activities of Bacillus subtilis isolated from cowdung microflora. Microbiological Research, 164(2), 121-130.

32.Vacheron, J., Desbrosses, G., Bouffaud, M.L., Touraine, B., Moënne-Loccoz, Y., Muller, D., Legendre, L., Wisniewski-Dyé, F. and Prigent-Combaret, C. (2013). Plant growth-promoting rhizobacteria and root system functioning. Frontiers in Plant Science, 4, 356.

33.Vaishnav, A., Jain, S., Kasotia, A., Kumari, S., Gaur,
R. K., and Choudhary, D. K. (2014). Molecular mechanism of benign microbe-elicited alleviation of biotic and abiotic stresses for plants. Approaches to Plant Stress and their Management. Springer, New Delhi. pp. 281-295.

34.Vaishnav, A., Varma, A., Tuteja, N., and Choudhary, D. K. (2016). PGPR-mediated amelioration of crops under salt stress. Plant-Microbe Interaction: An Approach to Sustainable Agriculture. Springer, Singapore. pp. 205-226

35.Vinale, F., Sivasithamparam, K., Ghisalberti, E. L., Marra, R., Woo, S. L., and Lorito, M. (2008). Trichoderma-plant-pathogen interactions. Soil Biology and Biochemistry, 40(1), 1-10.

36. Wargovich MJ (2000) Anticancer properties of fruits and vegetables. Horticultural Science 35 (4): 573-575 